\title{
IMPLIKASI HUKUM PEMBATASAN PERAN SERTA PEGAWAI NEGERI SIPIL DALAM PROSES POLITIK DI INDONESIA*
}

\author{
Tedi Sudrajat \\ Fakultas Hukum Universitas J enderal Soedirman Purwokerto \\ E-mail : t_sudrajat@yahoo.com
}

\begin{abstract}
In the form of philosophies, histories and comparative studies, limiting the political rights of civil Servant is a political outcome of the state to create a public official relations between the countries with the civil servant based on merit system that applies in the civil service law. The legal implications of the limiting the political rights of civil Servant which are : giving tribute, prohibition and administrative sanctions against the civil servant that involved in the process of politic in Indonesia.
\end{abstract}

Key words : civil servant, political participation, political system

\begin{abstract}
Abstrak
Melalui penelahan dari aspek filosofis, historis dan komparatif diketahui bahwa pembatasan hak politik Pegawai Negeri Sipil merupakan luaran dari politik kenegaraan guna menciptakan hubungan dinas publik melalui penerapan sistem merit dan didasarkan pada hasil evaluasi kinerja PNS dalam era sebelumnya. Adapun Implikasi hukum pembatasan partisipasi politik PNS dalam proses politik berupa munculnya pengaturan dan penegakan sanksi terhadap aturan yang tegas serta pembiaran terhadap aktivitas politik PNS atas aturan yang menimbulkan ambiguitas.
\end{abstract}

Kata kunci : Pegawai Negeri Sipil, partisipasi politik, sistem politik

\section{Pendahuluan}

Pada hakikatnya, demokrasi apabila dilihat dari bentuknya selalu diwarnai oleh pandangan hidup/ideologi bangsa. Secara substansial, hal ini menunjukan bahwa peran serta aktif rakyat di dalam pemerintahan selalu dilandasi oleh persamaan hak dan kemerdekaan/ kebebasan. ${ }^{1}$ Dalam kaitan ini, peran serta politik merupakan ukuran tentang betapa pentingnya kedudukan dan hubungan individu dalam negara. Makna yang terkandung adalah kebebasan dalam sistem politik merupakan konsekuensi logis atas hak-hak sipil dan politik sebagaimana termaktub dalam konsepsi hak asasi

\footnotetext{
- Artikel ini merupakan hasil penelitian tesis pada Program Magister IImu Hukum Unsoed tahun 2010.

1 Lihat M. Nur Hasan, "Tantangan Demokrasi di Indonesia", J urnal Aspirasi Magister IImu Hukum Trisakti, Vol. XVI (1) J uli 2006, hlm. 33-40
}

manusia melalui kehidupan kenegaraan dan kegiatan pemerintahan. ${ }^{2}$

Secara konstitusional, salah satu bentuk penerapan hak politik tercermin dalam hak untuk bebas berserikat, berkumpul dan mengeluarkan pikiran. ${ }^{3}$ Hak tersebut merupakan indikator bagi suatu negara telah melaksanakan demokrasi. Setiap negara yang mengaku sebagai

\footnotetext{
2 Hasnati, "Pertautan Kekuasaan Politik dan Negara Hukum", Jurnal Hukum Respublica Fakultas Hukum Universitas Lancang Kuning Pekanbaru, Vol. 3 (1) Tahun 2003, hlm. 110

3 Hak-hak yang diakui sebagai Hak-Hak Sipil dan Politik sebagaimana dilansir di Departemen Hukum dan HAM Republik Indonesia adalah (1) Hak hidup; (2) Hak bebas dari penyiksaan dan perlakuan tidak manusiawi; (3) Hak bebas dari perbudakan dan kerja paksa; (4) Hak atas kebebasan dan keamanan pribadi; (5) Hak atas kebebasan bergerak dan berpindah; (6) Hak atas pengakuan dan perlakuan yang sama dihadapan hukum; (7) Hak untuk bebas berfikir, berkeyakinan dan beragama; (8) Hak untuk bebas berpendapat dan berekspresi; (9) Hak untuk berkumpul dan berserikat; (10) Hak untuk turut serta dalam pemerintahan.
} 
negara hukum yang demokratis harus memasukkan aspek peran serta aktif rakyat di dalam konstitusinya yang dilandasi persamaan dan kemerdekaan/kebebasan. Di Indonesia, jaminan warganegara terhadap kebebasan berserikat, berkumpul dan mengeluarkan pikiran diatur Pasal 28E UUD Negara Republik Indonesia Tahun 1945 yang menyatakan bahwa setiap orang berhak atas kebebasan berserikat, berkumpul dan mengeluarkan pikiran, sedangkan jaminan yang sifatnya diakui secara Internasional diatur daIam ketentuan Article 20 Declaration of Human Right, yang menentukan, "everyone has the right to freedom of peacefull assembly and asociation and no one may be compilled to belong an association". Analog isi pasal tersebut adalah (1) setiap orang mempunyai hak atas kebebasan berkumpul dan berpendapat; (2) Tiada seorang juapun dapat dipaksa memasuki salah satu perkumpulan."

Pada dasarnya, kebebasan sebagaimana diuraikan dalam Article 20 Declaration of $\mathrm{Hu}$ man Right adalah bersifat universal, namun sebagaimana ditegaskan oleh Soewoto bahwa hak asasi ini bersifat universal, yang tidak universal adalah implementasinya dalam produk perundang-undangan. Ini diartikan bahwa, makna demokrasi dari kaca mata hukum terbagi menjadi dua yakni berkaitan dengan norma berupa cara memperoleh kekuasaan dan bagaimana melaksanakan kekuasaan ${ }^{4} \mathrm{Hal}$ inilah yang kemudian menimbulkan pembatasan terhadap peran serta Pegawai Negeri Sipil dalam proses politik.

Pernyataan di atas ditegaskan dalam Pasal 3 UU No. 43 tahun 1999 tentang Pokok-Pokok Kepegawaian yang menentukan:

1. Pegawai Negeri berkedudukan sebagai unsur aparatur negara yang bertugas untuk memberikan pelayanan kepada masyarakat secara profesional, jujur, adil, dan merata dalam penyelenggaraan tugas negara, pemerintahan, dan pembangunan;

2. Dalam kedudukan dan tugas sebagaimana di maksud dalam ayat (1), Pegawai Negeri ha-

\footnotetext{
4 Zulfirman, "Ontologi Demokrasi", J urnal Hukum FH Universitas Sultan Agung (UNISSULA) Semarang, Vol. 14 (2) J uni 2006, hlm. 137-138
}

rus netral dari pengaruh semua golongan dan partai politik serta tidak diskriminatif dalam memberikan pelayanan kepada masyarakat.

3. Untuk menjamin netralitas Pegawai Negeri sebagaimana dimaksud dalam ayat (2), Pegawai Negeri dilarang menjadi anggota dan/ atau pengurus partai politik.

Menurut S.F. Marbun, makna netralitas dalam Pasal 3 UU No.43 tahun 1999 diartikan dua hal. Pertama, bebasnya Pegawai Negeri Sipil dari pengaruh kepentingan partai politik tertentu atau tidak memihak untuk kepentingan partai tertentu atau tidak berperan dalam proses politik. Namun Pegawai Negeri Sipil masih tetap mempunyai hak politik untuk memilih, dan berhak untuk dipilih dalam pemilihan umum. Namun tidak diperkenankan aktif menjadi anggota dan pengurus partai politik; kedua, maksud netralitas yang lain adalah jika seorang Pegawai Negeri Sipil aktif menjadi pengurus partai politik atau anggota legislatif, maka ia harus mengundurkan diri. Dengan demikian birokrasi pemerintahan akan stabil dan dapat berperan mendukung serta merealisasikan kebijakan atau kehendak politik manapun yang sedang berkuasa dalam pemerintahan. ${ }^{5}$

Secara tekstual, makna netralitas tersebut seolah-olah menciptakan standar ganda terhadap kedudukan Pegawai Negeri Sipil, baik secara individu maupun institusi. Hal ini dikarenakan, netralitas yang dimaksud masih bersifat semu, artinya ranah politik bukanlah hal yang netral karena setiap Pegawai Negeri Sipil masih diberikan hak untuk memilih dan dipilih dalam konteks politik. Contoh atas ketidakpastian hukum (standar ganda) tersebut dapat dilihat dalam Pasal 11 UU No. 43 tahun 1999 yang menentukan bahwa Pegawai Negeri Sipil yang diangkat menjadi Pejabat Negara tidak kehilangan statusnya sebagai PNS, dan statusnya itu akan kembali apabila masa jabatan sebagai pejabat negara berakhir.

Mencermati Pasal 11 UU No. 43 tahun 1999, maka dapat ditafsirkan bahwa terdapat-

\footnotetext{
S.F. Marbun, 1998, Netralitas Pegawai Negeri Dalam Kehidupan Politik di Indonesia, Yogyakarta: Fakultas Hukum Universitas Islam Indonesia, hlm. 74
} 
nya peralihan status Pegawai Negeri Sipil menjadi Pejabat Negara yang berdampak pada pemberhentian sementara Pegawai Negeri Sipil dari jabatan organiknya tanpa kehilangan status karena setelah selesai menjalankan tugas sebagai pejabat negara dapat diangkat kembali dalam jabatan organiknya. ${ }^{6}$ Apabila dicermati kedudukan pejabat negara yang dimaksud dalam Pasal 11 ayat 1 huruf a, g, i, dan j, kedudukannya berkaitan erat dengan unsur politik ${ }^{7}$ dan terdapat kecenderungan dalam proses peralihan statusnya dipengaruhi oleh kepentingan partai politik tertentu, memihak kepentingan partai tertentu dan berperan dalam proses politik. Bukti lain dari adanya pemaknaan netralitas

\footnotetext{
6 Pengecualiannya terhadap Ketua, Wakil Ketua, dan Anggota Majelis Permusyawaratan Rakyat dan Ketua, Wakil Ketua, dan Anggota Dewan Perwakilan Rakyat (Pasal 11 huruf b dan c UU No. 43 Tahun 1999) karena menurut Pasal 50 ayat 1 huruf $k$ UU No. 10 tahun 2008 disebutkan bahwa bakal calon anggota DPR, DPRD Propinsi dan DPRD Kabupaten/Kota harus mengundurkan diri sebagai Pegawai Negeri Sipil, Tentara Nasional Indonesia, Anggota Kepolisian Negara Republik Indonesia, Pengurus BUMD dan atau BUMD serta badan lain yang anggarannya versumber dari keuangan negara yang dinyatakan dengan surat pengunduran diri yang tidak dapat ditarik kembali.

7 Sebagai contoh adalah posisi Presiden dan Wakil Presiden. Berdasarkan Pasal 6A ayat (1) UUD 1945 vide Pasal 8 UU No.42 Tahun 2008 tentang Pemilihan Umum Presiden dan Wakil Presiden menyatakan bahwa Calon Presiden dan calon Wakil Presiden diusulkan dalam 1 (satu) pasangan oleh Partai Politik atau Gabungan Partai Politik. Pasangan Calon yang diusulkan tersebut paling sedikit memiliki $20 \%$ (dua puluh persen) dari jumlah kursi Dewan Perwakilan Rakyat atau memperoleh 25\% (dua puluh lima persen) dari suara sah nasional dalam Pemilu anggota Dewan Perwakilan Rakyat, sebelum pelaksanaan Pemilu Presiden dan Wakil Presiden. Dalam hlm ini, penentuan calon Presiden dan/atau calon Wakil Presiden dilakukan secara demokratis dan terbuka sesuai dengan mekanisme internal Partai Politik bersangkutan (misalkan dengan cara konvensi, dlI) Partai Politik tersebut dapat pula melakukan kesepakatan dengan Partai Politik lain untuk melakukan penggabungan dalam mengusulkan Pasangan Calon (seperti: Golkar dengan Hanura, PDIP dengan Gerindra, Demokrat dengan PKS, PKB, PPP, PAN, dII) Partai Politik atau Gabungan Partai Politik tersebut hanya dapat mencalonkan 1 (satu) Pasangan Calon sesuai dengan mekanisme internal Partai Politik dan/atau musyawarah Gabungan Partai Politik yang dilakukan secara demokratis dan terbuka. Calon Presiden dan/atau calon Wakil Presiden yang telah diusulkan dalam satu pasangan oleh Partai Politik atau Gabungan Partai Politik tersebut kemudian tidak boleh dicalonkan lagi oleh Partai Politik atau Gabungan Partai Politik lainnya.
}

Pegawai Negeri Sipil yang sumir adalah keikutsertaan Pegawai Negeri Sipil secara aktif sebagai tim sukses (pemenangan) calon pejabat negara tertentu.

Berdasarkan penjabaran di atas, tulisan ini memiliki arti penting dalam hal menemukan teori yang terkait dengan hak-hak politik bagi Pegawai Negeri Sipil dan implikasi hukum atas hak tersebut. Dasar ketertarikan peneliti dikarenakan beberapa hal. Pertama, salah satu tuntutan masyarakat terhadap reformasi adalah reformasi birokrasi. Hal ini mengindikasikan proses birokratisasi pada masa orde baru banyak menerapkan praktik-praktik buruk, sehingga menimbulkan pantangan dan tantangan terhadap birokratisasi dalam era reformasi; ${ }^{8}$ kedua, baik buruknya suatu birokrasi negara sangat dipengaruhi oleh kualitas kepegawaian negaranya. Hal ini berarti sektor kepegawaian negara yang merupakan sub sistem dari birokrasi perlu dijadikan fokus dalam penelitian. Alasan yang mendasarinya adalah fakta keberhasilan pembangunan terletak pada usaha sistematis dan sungguh-sungguh untuk memperbaiki sistem kepegawaian negara, yang merupakan faktor dinamis birokrasi yang memegang peranan penting dalam semua aspek penyelenggaraan pemerintahan; ${ }^{9}$ ketiga, Undang-Undang No. 43 Tahun 1999 tentang Pokok-Pokok Kepegawaian merupakan produk hukum yang dikeluarkan pada era reformasi, karenanya nuansa pembentukannya dipengaruhi oleh kepentingan pemerintah dan warga negara dalam upaya menciptakan reformasi kepegawaian dalam rangka perubahan paradigma guna mewujudkan unsur aparatur negara yang bertugas memberikan pelayanan masyarakat secara profesional, jujur, adil, dan merata dalam penyelenggaraan

\footnotetext{
8 Lihat Yeremias T Keban, "Pokok-Pokok Pikiran Perbaikan Sistem Manajemen SDM PNS di Indonesia", J urnal Kebijakan dan Administrasi Publik MAP UGM, Vol. 8 (2) November 2004, hlm. 15-32; Lihat juga Andi Fefta Wijaya, "Kajian tentang Empat Agenda Reformasi Birokrasi", Jurnal Eksekutif STIE IBMT, Vol. 6 (1) Februari 2009, hlm. 12-18

9 J anry Haposan U.P. Simanungkalit, "Perkembangan Sistem Kepegawaian Negara: Perspektif Komparatif Amerika Serikat Dan Indonesia", Jurnal Kebijakan Dan Manajemen Badan Kepegawaian Negara, Vol. 1 (2) November 2007, hlm. 55
} 
tugas negara, pemerintahan, dan pembangunan; ${ }^{10}$ keempat, dalam format reformasi kepegawaian, terdapat konsep baru yang secara signifikan akan mempengaruhi proses kepegawaian yaitu netralitas. Hal ini memberikan arti negara memberikan pembatasan terhadap hak berkumpul/berserikat dan berpendapat bagi Pegawai Negeri Sipil dalam sistem politik di Indonesia, sehingga di dalamnya terkandung maksud adanya konsep-konsep perubahan paradigma Hukum Kepegawaian dan kemudian menerapkan standar baku pada setiap Pegawai Negeri Sipil. ${ }^{11}$ Namun permasalahan muncul saat terjadi perkembangan aktivitas kepegawaian yang memiliki sensitivitas dan subjektivitas bagi Pegawai Negeri Sipil dalam keterlibatannya di ranah politik. Aktivitas tersebut kemudian terbentur dalam pengaturan kepegawaian yang belum secara tegas menjelaskan mengenai hal tersebut.

\section{Perumusan Masalah}

Ada dua permasalahan yang akan dibahas pada artikel ini. Pertama, apakah yang mendasari pembatasan peran serta Pegawai Negeri Sipil dalam proses politik di Indonesia; dan kedua, bagaimanakah implikasi hukum terhadap pembatasan peran serta Pegawai Negeri Sipil dalam proses politik di Indonesia menurut perspektif Hukum Kepegawaian?

\section{Metode Penelitian}

Tipe penelitian yang digunakan adalah yuridis normatif dengan beberapa pendekatan masalah meliputi pendekatan Undang-undang, pendekatan konseptual, pendekatan sejarah dan pendekatan perbandingan. Penelitian ini difokuskan pada penelitian inventarisasi hukum dan penemuan terhadap asas-asas hukum. Pengumpulan bahan hukum dilakukan melalui metode kepustakaan dan metode dokumenter.

\footnotetext{
${ }^{10}$ Fajar Iswahyudi, “Urgensi Perubahan Karir PNS Menuju Tata Pemerintahan Yang Baik", J urnal Borneo Administrator, Pusat Kajian dan Pendidikan dan Pelatihan Aparatur III, LAN Samarinda, Vol. 4 (3) tahun 2008, hlm. 1426-1446

${ }^{11}$ Riyadi, "Reformasi Birokrasi Dalam Perspektif Perilaku Administrasi", Jurnal IImu Administrasi STIA LAN Bandung, Vol. V (1) Maret 2008, hlm. 104
}

Prosedur pengumpulan bahan hukum menggunakan sistem bola salju, dimana bahan-bahan hukum yang berhubungan dengan topik permasalahan, setelah itu dipergunakan sistem kartu dengan cara memaparkan sumber bahan hukum, disistematisasikan kemudian dianalisis guna menginterpretasikan hukum yang berlaku. Metode analisis yang digunakan adalah normatif kualitatif. Dalam menganalisis bahan hukum digunakan beberapa jenis interpretasi yang meliputi interpretasi gramatikal, interpretasi sistematis dan interpretasi menurut penetapan suatu ketentuan perundang-undangan (wet historische-interpretatie).

\section{Pembahasan}

\section{Alasan yang Mendasari Pembatasan Peran Serta Pegawai Negeri Sipil dalam Proses Politik di Indonesia}

Konsep yang mendasari pembatasan peran serta politik bagi Pegawai Negeri Sipil di Indonesia sangat erat kaitannya dengan peranan warga negara di dalam kehidupan bernegara dan berpemerintahan. Dalam kaitan ini, kehidupan para penyelenggara pemerintahan (administratur) senantiasa diarahkan dalam konteks politik kenegaraan dan kemudian berimbas pada cara berpikir, berkata dan bertindak dalam pekerjaannya. Untuk memperjelas hal tersebut, maka akan diuraikan pembatasan peran serta Pegawai Negeri Sipil dalam proses politik melalui 3 (tiga) aspek yang melandasinya yaitu aspek filosofis, landasan historis, dan Iandasan komparatif.

\section{Aspek Filosofis Pembatasan Hak Politik PNS}

Pada tingkat filosofis, peraturan pada hakikatnya merupakan upaya untuk memperoleh kepastian, kegunaan dan keadilan hukum guna membatasi kekuasaan terhadap kemungkinan kekuasaan bergerak atas nalurinya sendiri, yang akhirnya mengarah timbulnya penyalahgunaan kekuasaan (abuse of power). Gagasan mengenai kekuasaan harus dibatasi dikemukakan oleh Lord Acton yang mengingatkan bahwa pemerintahan selalu diselenggarakan oleh manusia dan pada manusia itu tanpa kecuali melekat banyak 
kelemahan. Dalilnya yang kemudian menjadi termashur adalah "manusia yang mempunyai kekuasaan cenderung untuk menyalahgunakan kekuasaan itu, tetapi manusia yang mempunyai kekuasaan tak terbatas pasti akan menyalahgunakan secara tak terbatas pula (Power tends to corrupt, but absolute power corrupt absolutely)."

Berdasarkan hal tersebut, pembatasan kekuasaan memiliki korelasi yang erat dengan upaya pembatasan perilaku dari penguasa. Artinya tidak ada satu pun peraturan yang keberlakuannya sepanjang zaman dan memenuhi kebutuhan realitas sosial yang terus berubah, sehingga setiap perubahan hakikatnya merupakan konsekuansi logis bagi setiap keinginan untuk memenuhi tuntutan zaman. Hal ini selaras dengan yang dinyatakan oleh Hart mengenai 3 (tiga) kaidah perilaku. Pertama, kaidah pengakuan (kaidah rekognisi) yang menetapkan kaidah perilaku mana yang di dalam sebuah masyarakat hukum tertentu harus dipatuhi; kedua, kaidah perubahan, yang menetapkan bagaimana suatu kaidah perilaku dapat diubah; ketiga, kaidah kewenangan, yang menetapkan oleh siapa dan dengan melalui prosedur yang mana kaidah perilaku ditetapkan dan bagaimana suatu kaidah perilaku harus diterapkan jika dalam suatu kejadian tertentu terdapat ketidakjelasan. Kewenangan terbagi menjadi kaidah kewenangan publik dan kaidah kewenangan perdata. Kaidah kewenangan publik dibagi menjadi kewenangan pembentukan Undang-Undang, kewenangan kehakiman, dan kewenangan pemerintahan. ${ }^{12}$

Mencermati kaidah perilaku tersebut, di dalam hubungan hukum antara negara dan Pegawai Negeri Sipil ditegaskan tentang ketentuan pembatasan perilaku pegawai yang bekerja dalam instansi negeri. Hubungan ini ini disebut sebagai hubungan dinas publik yang menurut Logemann, terjadinya apabila seseorang mengikatkan diri untuk tunduk pada perintah dari pemerintah melaksanakan sesuatu atau bebe-

\footnotetext{
12 J.J.H.Bruggink, 1999, Refleksi Tentang Hukum (Terjemahan Berhard Arief Sidharta), Bandung: Citra Aditya Bakti, hlm 104
}

rapa macam jabatan yang dalam pelaksanaannya itu dihargai dengan pemberian gaji dan beberapa keuntungan lain. Ini berarti inti hubungan dinas publik adalah kewajiban bagi pegawai yang bersangkutan untuk tunduk pada pengangkatan dalam beberapa macam jabatan tertentu yang mengakibatkan pegawai yang bersangkutan tidak menolak (menerima tanpa syarat) pengangkatannya dalam satu jabatan yang telah ditentukan oleh pemerintah, yang sebaliknya pemerintah berhak mengangkat seseorang pegawai dalam jabatan tertentu tanpa harus ada penyesuaian kehendak dari yang bersangkutan.

Hubungan dinas publik ini dalam penerapannya berkaitan dengan segi pengangkatan Pegawai Negeri yang dikenal dengan teori Contrac Suigeneris. Teori ini dikemukakan oleh Buys bahwa dalam Contract Suigeneris mensyaratkan pegawai negeri harus setia dan taat selama menjadi Pegawai Negeri, meskipun dia setiap saat dapat mengundurkan diri. Dari pendapat Buys ini dapat disimpulkan bahwa selama menjadi Pegawai Negeri Sipil, mereka tidak dapat melaksanakan hak-hak asasinya secara penuh. ${ }^{13}$ Karena itu, apabila PNS akan melaksanakan hak-hak asasinya secara penuh, pemerintah dapat menyatakan yang bersangkutan bukanlah orang yang diperlukan bantuannya oleh pemerintah. Dalam kaitan ini, Hukum Administrasi lebih memandang hubungan Hukum kepegawaian dimaksud sebagai hubungan Openbare Dienstbetrekking (hubungan dinas publik) terhadap negara (pemerintah). Openbare Dienstbetrekking yang melekat pada hubungan kepegawaian itu lebih merupakan hubungan sub-ordinatie antara bawahan dan atasan. ${ }^{14}$

Makna pemberlakuan hubungan dinas publik adalah timbulnya pembatasan terhadap diri Pegawai Negeri Sipil melalui peraturan yang dikenakan kepadanya, termasuk di dalamnya adalah hak-hak yang bersifat asasi. Dalam

\footnotetext{
${ }^{13}$ Tedi Sudrajat, "Problematika Penegakan Hukuman Disiplin Kepegawaian", J urnal Dinamika Hukum Fakultas Hukum UNSOED, Vol. 8 (3) september 2008, hlm. 214

${ }^{14}$ Philipus M. Hadjon, et.al, 1994, Pengantar Hukum Administrasi Indonesia, Yogyakarta: Gadjah Mada University Press, hlm. 214
} 
kaitan ini, walaupun hak asasi manusia diakui sebagai hak yang pada dasarnya tak dapat dikurangi, dirampas sedikitpun oleh siapapun, namun demikian hak asasi manusia bukanlah sesuatu yang bisa dinikmati tanpa batas. Terdapat adagium dalam hukum, yakni "penikmatan hak seseorang dibatasi oleh penikmatan hak orang lain." Ini memiliki makna yang sama dengan pernyataan dari J ohn Stuart Mill bahwa suatu perbuatan (penikmatan hak) tidak menimbulkan kerugian pada orang lain, menyebabkan tidak ada legitimasi bagi negara untuk merepresi suatu penikmatan hak. Sebaliknya jika memang penikmatan hak akan mengganggu orang lain, pembatasan terhadapnya dimungkinkan terjadi. Akan tetapi, perlu ditegaskan pembatasan itu haruslah ditentukan dengan hukum yang semata-mata untuk tujuan kesejahteraan umum dalam suatu masyarakat yang demokratik. Pasal 29 ayat (2) Universal Declaration of Human Right (UDHR) menentukan

In the exercise of his rights and freedoms, everyone shall be subject only to such limitations as are determined by law solely for the purpose of securing due recognition and respect for the rights and freedoms of others and of meeting the just requirements of morality, public order and the general welfare in a democratic society.

Pada level perundang-undangan nasional, Pasal 28 J (ayat1) UUD 1945 UUD 1945 memberikan pembatasan dan kewajiban hak asasi manusia dengan menyatakan: setiap orang wajib menghormati hak asasi manusia orang lain dalam tertib kehidupan bermasyarakat, berbangsa dan bernegara. Lebih lanjut Pasal $28 \mathrm{~J}$ ayat (2) menentukan

Dalam menjalankan hak dan kebebasannya, setiap orang wajib tunduk kepada pembatasan yang ditetapkan dengan Undang-Undang dengan maksud semata-mata untuk menjamin pengakuan serta penghormatan atas hak dan kebebasan orang lain dan untuk memenuhi tuntutan yang adil sesuai dengan pertimbangan moral, nilai-nilai agama, keamanan dan ketertiban umum dalam suatu masyarakat demokratis.
Hal di atas bermakna bahwa pembatasan politik bagi pegawai Negeri Sipil dapat ditolerir sepanjang untuk menjamin pengakuan serta penghormatan atas hak dan kebebasan orang lain, dan untuk memenuhi tuntutan yang adil sesuai dengan pertimbangan moral, keamanan, dan ketertiban umum dalam suatu masyarakat demokratis.

\section{Aspek Historis Pembatasan Hak Politik Pega- wai Negeri Sipil}

Berdasarkan sejarahnya, sifat dan arah hukum mengenai peran serta Pegawai Negeri Sipil dalam proses politik selalu diwarnai oleh kepentingan politik penguasa. Perjalanan politik bangsa menunjukkan kecenderungan yang sangat kuat bahwa birokrasi merupakan instrumen politik yang sangat efektif yang dibangun oleh sebuah rezim untuk membesarkan dan mempertahankan kekuasaan yang ada. Berkaitan dengan hal tersebut, untuk memperjelas perjalanan politik hukum terhadap kedudukan Pegawai Negeri Sipil dapat dicermati dengan penelaahan terhadap periode kekuasaan di Indonesia yang terbagi dalam 4 (empat) masa, yaitu masa awal kemerdekaan (1945-1949), masa demokrasi liberal sampai dengan masa demokrasi terpimpin/orde lama (1950-1965), masa orde baru (1965-1998) dan era reformasi (1998- sekarang).

\section{Politik Hukum Pemerintah pada Masa Awal Kemerdekaan (Tahun 1945-1950)}

Selama awal kemerdekaan, birokrasi tidak berjalan normal dan banyak dari pegawai yang terpecah belah. Selama revolusi fisik, ${ }^{15}$ pemerintah mengalami kesulitan untuk menata administrasi kepegawaian dengan baik, karena lembaga yang menangani administrasi kepegawaian belum terbentuk sepenuhnya. Pada awalnya, Kantor Urusan Pegawai (KUP) dibentuk berdasarkan Peraturan Pemerintah No. 11 Tahun 1948 Tanggal 30 Mei 1948 dan berkedudukan di

\footnotetext{
${ }^{15}$ Revolusi Fisik terjadi karena adanya perang dengan Tentara sekutu pada bulan Oktober 1945, agresi militer Belanda I tanggal 21 J uli 1947, pemberontakan PKI Madiun tanggal 18 September 1948, dan agresi militer Belanda II tanggal 19 Desember 1948.
} 
Yogyakarta. Dalam hal ini, KUP khusus diperuntukkan menangani pegawai pemerintah Republik Indonesia, sedangkan pegawai yang mengabdi pada pemerintah Hindia Belanda dikelola oleh Djawatan Umum Urusan Pegawai (DUUP) yang dibentuk berdasarkan Keputusan Gubernur Jenderal Hindia Belanda No. 13 Tahun 1948, berselang beberapa hari setelah lahirnya KUP. Dikarenakan masih dalam suasana revolusi, pemerintah republik tidak sekalipun mengubah organisasi birokrasi peninggalan Belanda kecuali menambah dengan disertakan Komite Nasional dalam mekanisme pemerin-tahan di daerah (KND).

Berdasarkan penjabaran tersebut, upaya pembatasan peran serta politik pada 1945-1950 bagi Pegawai Negeri Sipil belumlah ada. Ini terjadi karena situasi yang belum stabil dan belum adanya pengaturan tentang partai politik. Pada saat itu, aspek politik yang muncul adalah kepentingan untuk melegitimasi kekuasaan wilayah pemerintah Republik Indonesia dengan Belanda dengan cara mempertahankan dan menambah pegawai di wilayah yang dikuasai.

\section{Politik Hukum Pemerintah Pada Masa Demo- krasi Liberal sampai dengan Demokrasi Ter- pimpin (Tahun 1950-1965)}

Pada masa ini dikeluarkan Perpres No. 2 Tahun 1959 dan Surat Edaran (SE) Presiden Republik Indonesia No. 2 Tahun 1959 yang materinya membatasi kebebasan berpendapat sebagaimana tercantum dalam ketentuan Pasal 28 UUD 1945. Munculnya Perpres ini disebabkan oleh upaya pemerintah untuk memulihkan keadaan PNS yang pada saat itu berlarut-larut dalam permainan politik. Namun secara umum, perubahan politik ke era Demokrasi Terpimpin (1959-1966) tidak menghasilkan perubahan mendasar dalam proses birokratisasi kecuali perubahan peta kekuatan politik yang ditandai melalui tiga konteks. Pertama, peranan partai politik mulai termarjinalisasikan sebagai aktor utama dalam sistem politik; kedua, menonjolnya figur Presiden Soekarno sebagai patron kekuasaan; dan ketiga, masuknya kekuatan mili- ter secara resmi ke pentas politik, menempati banyak jabatan strategis pemerintahan dari pusat hingga daerah. Menurut Moh. Mahfud, keadaan pada masa demokrasi terpimpin juga dipengaruhi oleh produk hukum saat itu. Presiden menghendaki adanya Demokrasi Terpimpin, produk hukum yang dikeluarkan saat itu juga memiliki karakteristik yang dapat mendukung kebijakan Presiden. Demokrasi Terpimpin merupakan perwujudan kehendak Presiden dalam rangka menempatkan dirinya yang paling berkuasa di Indonesia. ${ }^{16}$

\section{Politik Hukum Pemerintah pada Masa Orde Baru (1965-1998)}

Pada era Orde Baru terdapat ciri-ciri dari model birokrasi yang berpolitik dengan dibentuknya wadah tunggal organisasi yaitu KORPRI, Bureaucratic Polity/Korporatisme Negara, Monoloyalitas Birokrasi/PNS saat Pemilu terhadap Partai Politik Pemerintah. Masyarakat termobilisasi dan terkooptasi. Perubahan dalam aspek politik pada era Orde Baru dapat ditandai melalui dua hal. Pertama, pola kontestasi kekuatan politik berubah dari polarisasi dan pertarungan antar-parpol dan politisi sipil ke pola dominasi militer dan Golongan Karya (Golkar). Kedua, proses marjinalisasi partai politik secara umum terus berjalan seiring dengan tampilnya unsur birokrasi dan kekuatan militer yang kian memantapkan posisi sebagai aktor sentral.

\section{Politik Hukum Pemerintah pada Era Refor- masi (1998-Saat ini)}

Pada era reformasi, dikeluarkannya beberapa peraturan yang membatasi peran serta Pegawai negeri Sipil dalam proses politik. Adapun ciri-ciri dari model netralitas politik birokrasi pada era reformasi yaitu KORPRI dinyatakan independen dari Partai Politik, birokrasi tidak berafiliasi politik, birokrasi berjarak dengan Partai Politik, birokrasi bersikap non diskriminatif terhadap Warga Negara dan partai politik, peran LSM dan kelompok kepentingan

\footnotetext{
${ }^{16}$ Afan Gaffar, 2000, Politik Indonesia:Transisi Menuju Demokrasi, Yogyakarta: Pustaka Pelajar, hlm. 29
} 
lebih leluasa dan masyarakat berpartisipasi secara otonom untuk membangun civil society.

\section{Aspek Komparatif Pembatasan Hak Politik PNS}

Berdasarkan analisis terhadap pengaturan hak politik di Amerika Serikat diketahui bahwa penggunaan sistem patronage ternyata menimbulkan permasalahan secara administratif, oleh karena itu partai-partai yang bersaing sepakat untuk memperbaiki manajemen kepegawaian dengan menjadikannya sebagai pegawai-pegawai negeri milik negara yang selalu siap digunakan oleh setiap partai pemenang di parlemen. Sejak itu, dibinalah Pegawai Negeri Sipil dengan disiplin tersendiri ke arah profesional. Dengan perkembangan pembinaan Pegawai Negeri Sipil ke arah merit system ${ }^{17}$, diatur jarak atau keikutsertaan pegawai negeri dalam kegiatan politik praktis melalui konsep netralitas, yang antara lain dengan cara penghapusan spoil system baik dalam rekrutmen maupun dalam pembinaan karier dan pengaturan masa jabatan.

Berdasarkan tersebut, penghapusan spoil system menciptakan Pegawai Negeri Sipil di Inggris memiliki sifat yang permanen, anonimitas dan Netral sedangkan pembatasan hak politik bagi Pegawai Negeri Sipil di Amerika Serikat berupa: Pertama, yang diterima menjadi pegawai federal harus mempunyai kesetiaan kepada negara bukan kepada partai; Kedua, untuk jabatan-jabatan tertentu diberlakukan ketentuan melarang menjadi simpatisan partai politik.

Kebijakan seperti itu kelihatannya mengurangi hak politik pegawai negeri, namun ternyata tidak dianggap merugikan diri pegawai yang bersangkutan, bahkan dalam beberapa hal dianggap sebagai kebanggaan. ${ }^{18} \mathrm{Hal}$ inilah yang kemudian mendasari pembatasan hak politik

\footnotetext{
${ }^{17}$ Merit system didefinisikan sebagai pengelolaan SDM yang didasarkan pada prestasi yaitu segenap perilaku kerja pegawai dalam wujudnya dikategorikan sebagai baik atau buruk, hal mana berpengaruh langsung pada naik atau turunnya penghasilan dan/atau karir jabatan pegawai. Lihat Arief Daryanto, "Merit Sistem dalam Manajemen Pegawai Negeri Sipil", Jurnal kebijakan dan Manajemen PNS Pusat Pengkajian dan Pelatihan BKN, Vol. 1 (2) November 2007, hlm. 2

${ }^{18}$ Dharma Setiawan Salam, 2007, Manajemen Pemerintahan Indonesia, J akarta: Djambatan, hlm. 194
}

bagi PNS di Indonesia melalui perubahan sistem yang mempengaruhi kinerja dan hak yang melekat pada diri PNS.

\section{Implikasi Hukum Pembatasan Peran Serta Pe- gawai Negeri Sipil dalam Proses Politik menu- rut Perspektif Hukum Kepegawaian}

Implikasi hukum merupakan akibat hukum yang akan terjadi berdasarkan suatu peristiwa hukum tertentu. Hal ini memberikan makna bahwa dalam implikasi hukum terkandung unsur hubungan hukum antar person, peristiwa hukum dan akibat hukum. Terkait dengan hal tersebut, implikasi hukum pembatasan peran serta PNS akan selalu didasarkan pada hukum positif. Di bawah ini dijelaskan beberapa implikasi hukum pembatasan peran serta pegawai negeri sipil dalam proses politik.

Pertama, terdapatnya aturan yang menimbulkan celah hukum sehingga dapat digunakan oleh Pegawai Negeri Sipil untuk berperan serta aktif dalam proses politik. Hal ini disebabkan oleh aturan yang berlaku kurang tegas (limitatif), namun lebih bersifat enumeratif sehingga menimbulkan kerancuan atau pertentangan interpretasi. Sebagai contoh adalah substansi Pasal 11 ayat (2) UU No. 43 Tahun 1999 yang memberikan gambaran bahwa Pegawai Negeri Sipil pada saat menjabat sebagai pejabat negara diberhentikan dari jabatan organiknya tanpa kehilangan statusnya sebagai Pegawai Negeri. Hal ini bermakna bahwa dimungkinkan seorang Pegawai Negeri Sipil ikut serta dalam proses pemilihan umum kemudian mengundurkan diri (sementara dari jabatan organiknya) dan setelah tidak terpilih atau terpilih menjadi pejabat negara, kembali menjadi Pegawai Negeri Sipil.

Kedua, terjadinya pengaburan makna netralitas Pegawai Negeri Sipil sebagaimana tercantum dalam Pasal 3 UU No. 43 Tahun 1999 tentang Pokok-pokok Kepegawaian yang dikarenakan dua hal, yaitu (a) dibolehkannya Pegawai Negeri Sipil menjadi pejabat negara melalui proses pemilihannya yang bersifat politis (UU No. 15 Tahun 2006, UU No. 39 Tahun 2008 dan UU No. 3 Tahun 2009). Pengaturan tentang me- 
kanisme pemilihan tersebut kemudian menghilangkan makna netral karena dalam praktiknya akan terjadi tarik ulur kepentingan di antara kepentingan politik dan kekuasaan; dan (b) dibolehkannya Pegawai Negeri Sipil menjadi peserta kampanye dan memiliki hak pilih (Pasal 84 ayat (4) UU No. 10 Tahun 2008). Dua hal yang bertentangan tersebut mengindikasikan bahwa pemerintah masih kesulitan dalam menempatkan makna netral dari pengaruh politik dan golongan tertentu. Apabila Pegawai Negeri Sipil ikut menjadi peserta kampanye, maka jelas dia memosisikan diri menjadi tidak netral, apalagi ketika dia memberikan hak pilihnya. Hal ini menimbulkan implikasi makna netralitas tidaklah relevan untuk dicantumkan dalam Pasal 3 UU No. 43 Ta-hun 1999.

Ketiga, terciptanya ambiguitas regulasi, karena pembatasan hak politik Pegawai Negeri Sipil yang dimaksudkan untuk menciptakan profesionalitas dalam diri Pegawai Negeri Sipil menjadi kabur karena pengaturan tentang kedudukan pejabat pembina Pegawai Negeri Sipil Daerah diserahkan kepada Kepala Daerah yang notabene merupakan pejabat politik yang dipilih melalui mekanisme politik (PP No. 9 Tahun 2003).

\section{Penutup}

\section{Simpulan}

Terhadap pembatasan peran serta PNS dalam proses politik didasarkan pada aspek filosofis, historis dan komparatif. Aspek filosofis di dasarkan pada konsep negara hukum demokratis yang berorientasi pada penerapan good governance guna menciptakan perubahan kaidah perilaku yang menempatkan hubungan dinas publik dalam hukum kepegawaian. Adapun dari aspek historis diketahui bahwa perjalanan politik bangsa didasarkan pada nilai sejarah dan berubah seiring praktik buruk yang telah berlangsung. Landasan komparatif menggambarkan bahwa system kepgawaian di Amerika Serikat menunjukan pembaharuan sistem patronage ke arah merit system. Melalui merit system, diatur jarak atau keikutsertaan pegawai negeri dalam kegiatan politik praktis melalui konsep netralitas menggunakan sifat yang permanen, anonimitas dan netral.

Implikasi hukum pembatasan peran serta Pegawai Negeri Sipil dalam proses politik, berupa inkonsistensi pengaturan tentang netralitas yang meliputi adanya aturan yang menimbulkan celah hukum, sehingga dapat digunakan oleh Pegawai Negeri Sipil untuk berperan serta aktif dalam proses politik, terjadinya pengaburan makna netralitas dan terciptanya ambiguitas regulasis.

\section{Saran}

Ada beberapa saran yang diberikan penulis. Pertama, substansi Pasal 11 Undang-Undang No.43 tahun 1999 tentang Pokok-Pokok Kepegawaian perlu diuji materiil karena menimbulkan penafsiran ganda dalam pelaksanaannya; Kedua, penggunaan definisi netralitas Pegawai Negeri Sipil kurang relevan, sebaiknya kata netralitas Pegawai Negeri Sipil diganti dengan pembatasan hak politik Pegawai Negeri Sipil; Ketiga, perlu adanya perubahan pengaturan terhadap pejabat pembina kepegawaian daerah yang memiliki kewenangan Pengangkatan, Pemindahan dan pemberhentian Pegawai Negeri Sipil.

\section{Daftar Pustaka}

Bruggink, J.J.H.1999. Refleksi Tentang Hukum. (Terjemahan Berhard Arief Sidharta). Bandung: Citra Aditya Bakti;

Daryanto, Arief. "Merit Sistem dalam Manajemen Pegawai Negeri Sipil". Jurnal Kebijakan dan Manajemen PNS Vol. 1 No. 2 November 2007. Pusat Pengkajian dan Pelatihan BKN;

Gaffar, Afan. 2000. Politik Indonesia:Transisi Menuju Demokrasi. Yogyakarta: Pustaka Pelajar;

Hadjon, Philipus M. et.al. 1994. Pengantar Hukum Administrasi Indonesia. Yogyakarta: Gadjah Mada University Press;

Hasan, M. Nur. "Tantangan Demokrasi di Indonesia". J urnal Aspirasi Magister IImu Hukum Trisakti, Vol. XVI No. 1, J uli 2006;

Hasnati. "Pertautan Kekuasaan Politik dan Negara Hukum". Jurnal Hukum Respublica 
Vol. 3 No. 1 Tahun 2003. Fakultas Hukum Universitas Lancang Kuning Pekanbaru;

Iswahyudi, Fajar. "Urgensi Perubahan Karir PNS Menuju Tata Pemerintahan yang Baik". J urnal Borneo Administrator Vol. 4 No. 3, 2008. Pusat Kajian dan Pendidikan dan Pelatihan Aparatur III, LAN Samarinda;

Keban, Yeremias T. "Pokok-Pokok Pikiran Perbaikan Sistem Manajemen SDM PNS di Indonesia". J urnal Kebijakan dan Administrasi Publik Vol. 8 No. 2 November 2004. MAP UGM;

Marbun, S.F. 1998. Netralitas Pegawai Negeri dalam Kehidupan Politik di Indonesia, Yogyakarta: Fakultas Hukum Universitas Islam Indonesia;

Riyadi. "Reformasi Birokrasi Dalam Perspektif Perilaku Administrasi". J urnal IImu Administrasi Vol. V No. 1, Maret 2008. STIA LAN Bandung;
Salam, Dharma Setiawan. 2007. Manajemen Pemerintahan Indonesia. J akarta: Djambatan;

Simanungkalit, J anry Haposan U.P. "Perkembangan Sistem Kepegawaian Negara: Perspektif Komparatif Amerika Serikat dan Indonesia"; Jurnal Kebijakan dan Manajemen Vol. 1 No. 2, November 2007. Badan Kepegawaian Negara;

Sudraj at, Tedi. "Problematika Penegakan Hukuman Disiplin Kepegawaian". Jurnal Dinamika Hukum Vol. 8 No. 3 september 2008. Fakultas Hukum UNSOED,

Wijaya, Andi Fefta. "Kajian tentang Empat Agenda Reformasi Birokrasi". Jurnal Eksekutif Vol. 6 (1) Februari 2009. STIE IBMT;

Zulfirman. "Ontologi Demokrasi". Jurnal Hukum Vol. 14 No. 2, J uni 2006. Semarang: FH Universitas Sultan Agung (UNISSULA). 